\section{Hanyang Medical R evi ews}

Hanyang Med Rev 2013;33:165-169

http://dx.doi.org/10.7599/hmr.2013.33.3.165

pISSN 1738-429X eISSN 2234-4446

\section{정형외과 영역에서의 기초연구 현황}

\section{임군일}

동국대학교 일산병원 정형외과

\title{
Current Status of Basic Research in Orthopaedics
}

Gun-II Im

Department of Orthopaedics, Dongguk University llsan Hospital, Goyang, Korea

Orthopaedic medicine has developed and benefited from the advancement of related basic science. Current technologies such as joint replacement and internal fixation of fractures started from research on biocompatible biomaterials and on the understanding of body biomechanics. As ongoing research on life science may dramatically change the appearance of future orthopaedic medicine, it is very important to keep abreast with recent trends of related basic science. This review introduces the realm of basic sciences related to orthopaedic medicine along with comments on future perspectives.

Key Words: Orthopedics; Biomedical Research; Review
Correspondence to: Gun-Il Im 우410-773, 경기도 고양시 일산동구 동국 로 27 , 동국대학교 일산병원 정형외과 Department of Orthopaedics, Dongguk University Ilsan Hospital, 27 Dongguk-ro, Ilsandong-gu, Goyang 410-773, Korea Tel: $+82-31-961-7315$ Fax: +82-31-961-7314 E-mail: gunil@duih.org

Received 22 May 2013

Revised 25 July 2013

Accepted 31 July 2013

This is an Open Access article distributed under the terms of the Creative Commons Attribution Non-Commercial License (http://creativecommons.org/licenses/by-nc/3.0) which permits unrestricted non-commercial use, distribution, and reproduction in any medium, provided the original work is properly cited.

\section{서 론}

서양의학은 과학적인 사실과 분석방법에 학문의 토대를 두고 있 다. 17 세기 이후 전통적인 근거가 불분명한 학설을 대신하여 관찰 과 실험을 통하여 확인된 사실을 바탕으로 하여 질병의 원인과 치 료를 하려는 시도가 이루어졌고 19세기에는 의학의 비약적인 발전 과 함께 의학은 직업의 영역이기보다는 과학의 한 분야가 되었다. 물론 그렇다 하더라도 임상의학의 목적은 환자의 질병치유를 최종 목적으로 하며 임상의학에서는 과학의 영역을 벗어난 경험과 기술 에 의존하는 부분이 분명히 있음을 부인할 수 없으나 현대의학으 로 갈수록 과학에 해당하는 부분의 비중이 커지고 있으며 그 결과 로 치료의 재현성과 예측가능성이 높아지고 있다.

19 세기까지 거의 대부분의 기초의학 연구자는 임상을 같이 하 는 의사들이었으며 임상의 경험을 가진 의사가 과학의 방법론을
이용하여 기초의학을 연구하고 그 결과가 다시 환자 치료에 이용되 어 기초의학과 임상의학의 괴리는 크게 찾아 보기 힘들었다. 그러 나 20세기부터는 광범위한 과학의 발전 및 세분화로 인하여 임상 의사가 많은 환자를 진료하면서 나날이 달라지는 기초의학의 모든 분야를 알기는 어려웠고 많은 의과대학에는 진료를 보지 않고 기초 연구만 하는 의사가 등장하였다. 해부학, 생화학, 생리학 등 기초의 학교실에 소속되어 교육 및 연구를 담당하는 시스템이 자리잡게 되 었다.

최근 생명과학의 급속한 발전은 그 지식이 임상의학에 이용될 때까지의 지연 시간(translational gap)을 크게 만들었으며 제한된 수의 기초의학 전공자가 그 지식이 임상에 적용될 수 있게 맞추어 가져오는 것이 어려운 일을 감안 할 때, 기초연구를 이해하고 일부 수행하면서 의사가 아닌 기초연구자와 소통할 수 있는 임상의사의 필요성이 다시 대두되었다. 미국에서는 이점을 이해하여 기초연구 
를 수행할 수 있는 임상의사를 대규모 연구의 책임자로 하여 거액 의 연구비를 집행할 수 있게 하는 연구수행체계가 자리잡게 되었 고 따라서 대학병원 급의 대형의료기관에서는 이러한 기초연구능 력을 갖춘 임상의사를 중요시하게 되었다. 일본의 경우 대학병원의 진료부담이 적은 편이며 특유의 의국 운영체계상 수련의사가 기초 연구와 환자진료 트랙을 3-4년 주기로 번갈아 수행하기 때문에 대 학병원에 오래 근무할 의사가 아니어도 수련과정 중 상당한 시간의 기초연구를 수행하게 되어있다. 그 결과로 기초연구의 저변이 넓어 졌으며 이는 노벨상수상자(Shinya Yamanaka)가 임상의학 전공자 중에서 나올수 있게 하는 원동력이 되고 있다.

우리나라에서는 임상교실의 기초연구는 주로 박사학위논문을 위한 실험연구를 기초의학교실의 자문과 시설을 빌어 시행하거나 동물실험을 자체 수행하는 정도 수준의 연구를 수행하였고 그 연 구비는 대개 학위후보자가 부담하는 형식이었으나, 80 년대 들어와 서 유수 대학병원에서는 자체의 실험연구시설을 갖추기 시작하면 서 연구의 질도 높아지기 시작하였다. 90년대 중반 이후 보건복지 부에서 임상의사를 수혜자로 하는 연구비가 생겨나기 시작하였으 며 최근까지 계속 증가하여 왔다. 그 결과 국내 의과대학에서 국제 의학지 게재건수가 기하급수적으로 증가하였고, 선진국의 연구자 들로부터도 인정받기 시작하였다.

정형외과는 근골격계의 질환을 내과적, 외과적, 물리적으로 연 구하고 진단, 치료하는 분야로서[1] 다양한 범주의 기초과학과 연 관이 되었으며 현재 정형외과의 앞선 치료는 상당부분을 이들 기초 과학의 발전에 의거하고 있다. 생명과학의 연구결과에 따라 미래 근골격계의 치료는 아주 달라질 수 있다. 근골격계 외상과 질환에 있어 외과적 치료방법이 20 세기에 진입하기 전까지는 거의 전무하 였다는 점을 생각하면 이점을 이해하기 쉬울 것이다. 분자의학과 세포치료의 발달은 반대로 향후 수십 년 내에 근골격계의 수술적 치료에 대한 수요를 급격히 줄여 정형외과의 “외과”적인 성격이 거 의 없어질 가능성도 생각할 수 있는 일이다. 따라서 관련된 기초과 학에 대하여 잘 알고 있으면서 그 변화를 이해하고 수용하며, 가능 하면 기초학문의 발전에 동참하는 것이 좋은 근골격계 전문가의 길 이라고 생각한다.

본 고에서는 정형외과 영역과 관련된 기초연구분야를 간략히 소 개하여 이제 관심을 갖기 시작하는 젊은 연구자들께 작은 지침을 드리고자 한다.

\section{정형외과와 관련된 기초과학}

\section{1. 생체재료학}

생체재료는 일반적으로 인체에 적용하여 질병을 치료하고 손상 된 조직이나 장기를 대신하는 목적으로 가용하는 재료를 말하는 데 미국 국립 보건원에서는 생체재료(biomaterials)를 인공 또는 천
연 소재로서 일정 기간 동안 생체의 조직, 장기 또는 기능 전체 또는 일부를 처치, 보강 또는 대체하는데 사용되는 물질이나 그것의 조 합으로 정의하고 있다[1,2].

정형외과에서는 골과 관절의 기능을 대체하는 보형물(인공관절 등)이나 골절의 고정을 위한 내고정 재료로서 금속, 세라믹, 중합체 등을 개발하여 이용하여 왔다. 이들 재료들은 스텐레스강과 같이 최초로 개발된 상태로 이용되는 경우도 있으나 생체에서 장시간 사 용하면서 발생하는 문제들을 해결하기 위하여 계속적으로 연구되 며 개선되고 있는데 그 예로서는 인공관절의 베어링으로 사용되는 교차결합 폴리에틸렌(crosslinked polyethylene) 및 2세대 세라믹 인공관절들을 들 수 있다. 주로 골과 연골을 대체할 수 있는 경도가 높은 금속, 세라믹 등이 주 연구대상이었으나 최근에는 골 및 연골 의 조직재생을 위한 담체로서 다양한 다공성 지지체 및 하이드로 겔 등이 연구되고 있으며 기존의 인공관절의 표면에 기능성 물질을 입힌 새로운 재료들이 연구되고 있다. 생체재료학은 생물학적 기능 을 모두 갖추어 그 기능을 수행할 수 있는 인공장기를 최종목적으 로 하는 만큼 앞으로도 계속 발전할 수 있는 정형외과학과 불가분 의 관계에 있는 기초연구 분야라고 할 수 있다.

\section{2. 생체역학}

생체역학은 역학적인 방법을 이용하여 사람, 동물, 식물, 장기, 세 포 등 생물학적 시스템을 연구하는 학문으로 정의된다[3]. 생체역 학은 우리 몸의 골과 관절, 근육의 기능을 이해하기 위하여 시작되 었으며 주로 사체를 이용한 생체실험을 기본으로 하며 분석법과 컴 퓨터를 이용한 가상모델을 이용한 연구도 많이 시행되고 있다. 인 공관절 등의 보형물이나 척추와 골절 내고정물이 인체조직에 어떤 영향을 미칠 것인 가을 연구하는 분야가 임상응용에 있어 중요한 분야이며 골다공증 등 골의 기질적인 변화 및 골절위험과의 관계 의 해석이 최근의 생체역학의 새로운 분야로서 등장하고 있다. 관 절면의 마찰, 마모, 윤활을 연구하는 마찰학(tribology) 역시 인공 관절과 관계되어 많이 연구되고 있는 분야이다.

\section{3. 골생물학}

골의 발생과 형성, 흡수에 관한 생물학적 현상을 연구하는 골생 물학은 최근 골다공증의 합병증이 큰 문제로 대두되면서 그 중요 성이 더하여지고 있다. 이 분야는 치과대학이나 내분비 내과에서 도 활발하게 연구하고 있는 분야이며 최근 골흡수와 면역계의 관 련성이 발견되어 골면역학(osteoimmunology)이라는 새로운 연구 분야가 만들어 지기도 했다. 정형외과 의사들은 전통적으로 골흡 수보다는 골절유합의 기전과 관련되어 골형성(bone formation)에 더 많은 관심을 보여 왔으나 최근의 개념은 골형성과 골흡수는 서 로 연관이 되어 있기 때문에 두 분야에 대한 깊은 이해가 골생물학 에 있어 중요하다고 사료되고 있다. 


\section{4. 연골생물학 및 골관절염 연구}

연골생물학은 주로 골관절염의 기전과 관계되어 많이 연구되어 왔으며 류마티스 내과에서도 연구되는 분야이다. 최근 연골재생이 임상적으로 적용 가능할 것으로 예측되면서 더욱 활발하게 연구되 고 있다. 골관절염의 병인론에 있어 이화인자와 동화인자, 연골파괴 에 관계되는 효소에 관한 연구가 많이 진행되어 있으나 최근에는 연골세포의 배양에 있어 표현형을 유지하는 방법, 줄기세포로부터 분화기전, 비후억제의 연구 등이 주된 화두로 등장하고 있다.

\section{5. 근골격계의 줄기세포 및 재생의학}

근골격계의 질환은 줄기세포/재생의학의 임상적용에 있어 가장 수요가 많고 적용하기 쉬운 분야 중 하나로 국내에서도 제대혈줄기 세포를 이용한 관절염 줄기세포 치료제가 개발된 바 있다. 우리나 라에서는 국가적으로 줄기세포에 대한 기초 및 응용연구를 지원하 고 있으며 많은 연구자들이 참여하고 있다.

근골격계 줄기세포/재생의학의 목적은 현재 인공관절이나 동종 이식으로 치료하고 있는 골관절의 질환들에 대한 비침습적 대체 치료법의 개발이며 근골격계 질환을 성공적으로 치료할 수 있을 가능성은 상당히 높다고 사료되나 아직도 조기 병변에 적용할 수 있는 예측가능하고 안전한 치료제 개발까지는 갈 길이 멀고 밝혀 야 할 연구내용들이 많다. 따라서 이 분야는 아직도 성장기에 있는 학문이며 근골격계 연구자들의 할 일이 많다고 사료된다.

\section{줄기세포를 이용한 연골 재생연구의 최신 동향}

초기에는 근골격계의 줄기세포/조직재생이 주된 테마로 연구 되 었으며 골관절염의 발생기전에 대한 연구도 진행되고 있다. 현재 연 구의 기법은 분자생물학적 분석에서 시작하여 현재는 유전자전달, 나노의학, 후성유전학등 다양한 방법(tool)을 이용하여 현상규명 과 기반기술 개발에 힘쓰고 있다.

\section{1. 근골격계 줄기세포/조직재생 연구의 시작}

정형외과영역의 기초연구는 90년대 초까지는 생체역학이나 생 체재료의 시험, 수술적 처치의 영향을 간단한 동물실험을 통하여 보는데 그치고 있었으며 생체현상의 세포생물학, 분자생물학적 분 석은 거의 시도되고 있지 않았다. 1994년 New England Journal of Medicine에 Brittberg 등[4]이 배양된 연골세포의 이식에 의한 연 골결손의 치유를 발표한 후 정형외과 영역에서의 재생의학이 관심 을 받게 되었다. 또한 미국 Cleveland 대학의 Caplan 등[5]은 골수 의 기질세포(bone marrow stromal cell)가 여러 세포로 분화할 수 있는 줄기세포의 성질을 가지고 있음을 밝히고 이를 간엽줄기세포 (mesenchymal stem cell)라 명명하였다. 우리나라에서도 1990년대 후반부터 임 등[6]의 연구에 의해 근골격계 조직재생에 대한 연구
가 시작 되었다. 또한 지방에서 유래한 간엽줄기세포를 이용한 골 과 연골의 재생에 대한 연구도 진행되고 있는데, 이 연구는 성체줄 기세포의 원천으로 많은 장점을 가진 지방기원의 간엽줄기세포의 골 및 연골형성능력이 지금까지 알려진 배양조건에서는 골수기원 의 간엽줄기세포에 비하여 크게 다르다는 것을 증명하여 이 세포 를 임상적으로 이용하기 위해서 최적의 배양조건에 대한 탐색이 다 시 필요하다는 것을 제시한 중요한 연구이다[7]. 또한 배양된 골수 간엽세포에 의한 연골형성에 대한 연구도 수행되어 성체줄기세포 로 가장 많이 쓰이는 골수줄기세포가 고령층에서도 적절한 성장 인자의 조건에서 동물혈청의 투여 없이도 충분히 증식하고 연골형 성을 할 수 있음을 밝히고 그 적절한 성장인자의 조건을 알아내어 고령자에서 얻은 간엽줄기세포가 조직공학적인 연골재생에 활용 될 수 있는 길을 찾았다[8]. 추가적으로 배양된 간엽줄기세포에서 연골로의 분화를 촉진시키기 위한 성장인자의 최소조건에 대한 연 구가 진행되었는데 초기에 1-2회의 transforming growth factorbeta (TGF- $\beta$ )의 투여로 충분한 연골형성을 얻을 수 있다면 조직공 학적인 신생연골의 형성이 좀 더 경제적으로 이루어질 수 있다는 가설에서 출발하였으나, 실제 결과에서는 연골형성의 정도는 TGF$\beta$ 의 투여회수에 비례하여 계속적인 투여가 필요하다는 결론을 얻 었다[9].

또한 지방줄기세포에서 골수기원의 간엽줄기세포만큼 연골형성 을 유도할 수 있는 성장인자의 조건을 탐색하여 TGF- $\beta$ 와 insulinlike growth factor type-I(IGF-I)의 고농도 투여 시 골수 간엽줄기 세포에서만큼 연골을 형성 함을 밝혔다[10]. TGF- $\beta$ 와 여러 bone morphogenetic protein (BMP)의 다양한 조합을 시도한 결과 TGF$\beta 2$ 와 BMP7의 조합이 효과적임과[11] 연골세포와의 공배양 또는 연골세포의 배양액이 지방줄기세포의 연골분화를 촉진함이 증명 되었다[12].

\section{2. 간엽줄기세포에서 신호전달체계의 조절에 의한 연골분화}

조직분화의 유도를 처음에는 단백질, 펩타이드인 성장인자를 이 용하여 분화유도 하였으나 세포 내 신호전달에 관여하는 small molecule을 이용하여 유도를 할 수 있다는 생각을 하게 되었다. 간 엽줄기세포로부터 연골세포로의 분화에 있어 MAP kinase pathway와 parathyroid hormone-related protein-indian hedgehog (PTHrP-IHH) axis의 변화가 연골분화의 촉진과 연골세포의 비후 (hypertrophic change)를 막을 수 있다는 가정을 가지고 $\mathrm{PTHrP}$ 와 PD98059 (ERK inhibitor)를 배양 후기에 투여한 결과 연골형성을 촉진시키면서 비후를 억제할 수 있었고[13,14], 근골격계의 발생에 중요한 역할을 하는 Wnt 신호전달체계의 억제가 간엽줄기세포로 부터 연골세포로의 분화를 촉진시킴이 증명되었다[15,16]. 


\section{3. 유전자(전사인자)의 이입에 의한 줄기세포의 연골 및 골 분화촉진}

2004년 연골형성에 있어 필수 전사인자(master transcription factor)인 sox-9과 보조인자(co-factor)인 섬유모세포(fibroblast)에 sox-5,6을 아데노바이러스를 이용하여 이입(adenoviral transduction) 시킬 경우 연골세포와 같은 성질의 세포를 만든다는 보고를 시작으로 sox-5,6,9를 전기충격에 의해(electroporation) 골수줄기 세포와 지방줄기세포에 이입하여 배양한 결과 세가지 인자가 모두 이입된 경우 분화인자인 TGF- $\beta$ 와 BMP의 투여가 없이도 연골형성 표지자인 type II collagen의 증가와 함께 미분화된 세포에서 크게 발현되는 type I collagen의 감소 및 연골세포의 비후를 나타내는 type X collagen의 감소를 유도하여 연골형성을 크게 촉진함을 알 수 있었다[17,18]. SOX trio gene의 레트로바이러스를 이용한 이입 (retroviral transduction)이 쥐의 연골결손과 퇴행성관절염을 치유 하는데 도움을 주는 것을 확인하였다[19].

SOX trio 유전자가 함유되어 서서히 방출되면서 파종(seeding) 된 세포를 유전자전달감염(transfection)시켜 연골분화를 유도하 는 PLGA scaffold system에 지방줄기세포를 파종하여 토끼의 연골 결손에 이식한 결과 좋은 치유결과를 얻어 앞으로 임상에서 이용 할 수 있는 기초자료를 확보하였다[20].

골형성 촉진과 관련하여 지방줄기세포에 골분화의 필수 전사인 자인 Runx-2와 osterix를 electroporation 한 후 배양한 결과 골형 성 표지자인 알칼리인산분해효소(alkaline phosphatase), 오스테 오칼신(osteocalcin), type I collagen, bone sialoprotein의 발현이 증 가함을 발견하였고 그 정도는 Runx-2를 이입한 경우 osterix 보다 훨씬 컸으며 Runx-2를 이입한 경우 osterix의 단백발현이 같이 증 가함을 탐지하여 지방줄기세포의 골분화를 촉진시키는 시스템이 개발되었다[21].

\section{4. 골관절염의 후성유전학적인 차이}

골관절염의 후성유전학적 차이를 규명하기 위해서 쥐 무릎의 퇴 행성 관절염의 관절연골과 정상연골에서, 그리고 사람 무릎의 퇴행 성 관절연골에서 심하게 이환된 부분과 덜 이환된 부분의 Sox-9의 메틸화(methylation) 정도의 차이가 확인되었으며 사람의 고관절 에 있어서 정상연골 10 예와 퇴행성 고관절에 이환된 연골 10 예에서 SOX-9 유전자의 촉진자(promoter)를 $-5.0 \mathrm{~kb}$ 까지 조사한 결과 메 탈화가 퇴행성 연골에서 현저하게 증가됨을 관찰하여 동화인자의 후성유전학적 변화와 골관절염과의 상관관계를 규명하였다[22].

\section{향후의 전망}

정형외과 영역의 질환은 생명을 직접적으로 위협하는 경우보다 는 통증과 장해를 유발하여 삶의 질을 저하시키는 경우가 많다. 국
가 보건사업에 있어서도 근골격계의 질환이 암과 심장, 신경질환에 비하여 우선 순위가 밀리는 경우를 많이 볼 수 있으나 선진국으로 진입하고 소득수준이 올라갈수록 단순한 수명의 연장보다는 삶의 질이 우선시 되며 근골격 관련 의료비용이 크게 증가하게 되며 이 러한 문제를 해결하기 위하여 관련된 기초연구가 필요하다는 점이 인식되게 된다.

우리나라의 경우 근골격계 의학연구의 중추를 담당해야 할 대학 병원의 교수진들이 임상진료의 부하량에 허덕이면서 기초연구가 등한시되어 소수의 연구자만이 적정연구비를 확보하여 국내에서 도 이 분야의 연구를 주도하지 못하고 다른 선진국에 비하여 상당 히 뒤처져 있는 실정이다. 빠른 시간 내에 현상의 변화를 불러 오는 것은 어려운 일이지만 향후 지속적인 관심을 보이고 남다른 노력을 경주하면 우리나라에서도 미국, 일본, 유럽에 못지 않는 연구수준 에 도달할 수 있을 것으로 생각된다.

\section{REFERENCES}

1. The Korean Orthopaedic Association. Orthopaedics. 6th ed. Seoul: The Korean Orthopaedic Association; 2006:3-4, 62-7.

2. The Korean Society for Biomaterials. Biomaterials. Seoul: Freedom Academy Publishing; 2009:10-181.

3. Hatze H. Letter: The meaning of the term "biomechanics". J Biomech 1974;7:189-90.

4. Brittberg M, Lindahl A, Nilsson A, Ohlsson C, Isaksson O, Peterson L. Treatment of deep cartilage defects in the knee with autologous chondrocyte transplantation. N Engl J Med 1994;331:889-95.

5. Caplan AI. Mesenchymal stem cells. J Orthop Res 1991;9:641-50.

6. Im GI, Kim DY, Shin JH, Hyun CW, Cho WH. Repair of cartilage defect in the rabbit with cultured mesenchymal stem cells from bone marrow. J Bone Joint Surg Br 2001;83:289-94.

7. Im GI, Shin YW, Lee KB. Do adipose tissue-derived mesenchymal stem cells have the same osteogenic and chondrogenic potential as bone marrow-derived cells? Osteoarthritis Cartilage 2005;13:845-53.

8. Im GI, Jung NH, Tae SK. Chondrogenic differentiation of mesenchymal stem cells isolated from patients in late adulthood: the optimal conditions of growth factors. Tissue Eng 2006;12:527-36.

9. Kim HJ, Kim YJ, Im GI. Is continuous treatment with transforming growth factor-beta necessary to induce chondrogenic differentiation in mesenchymal stem cells? Cells Tissues Organs 2009;190:1-10.

10. Kim HJ, Im GI. Chondrogenic differentiation of adipose tissue-derived mesenchymal stem cells: greater doses of growth factor are necessary. J Orthop Res 2009;27:612-9.

11. Kim HJ, Im GI. Combination of transforming growth factor-beta2 and bone morphogenetic protein 7 enhances chondrogenesis from adipose tissue-derived mesenchymal stem cells. Tissue Eng Part A 2009;15:154351.

12. Lee JS, Im GI. Influence of chondrocytes on the chondrogenic differentiation of adipose stem cells. Tissue Eng Part A 2010;16:3569-77.

13. Kim YJ, Kim HJ, Im GI. PTHrP promotes chondrogenesis and suppresses hypertrophy from both bone marrow-derived and adipose tissue-derived MSCs. Biochem Biophys Res Commun 2008;373:104-8.

14. Kim HJ, Im GI. The effects of ERK1/2 inhibitor on the chondrogenesis of bone marrow- and adipose tissue-derived multipotent mesenchymal 
stromal cells. Tissue Eng Part A 2010;16:851-60.

15. Im GI, Quan Z. The effects of Wnt inhibitors on the chondrogenesis of human mesenchymal stem cells. Tissue Eng Part A 2010;16:2405-13.

16. Im GI, Lee JM, Kim HJ. Wnt inhibitors enhance chondrogenesis of human mesenchymal stem cells in a long-term pellet culture. Biotechnol Lett 2011;33:1061-8.

17. Im GI, Kim HJ. Electroporation-mediated gene transfer of SOX trio to enhance chondrogenesis in adipose stem cells. Osteoarthritis Cartilage 2011;19:449-57.

18. Kim HJ, Im GI. Electroporation-mediated transfer of SOX trio genes (SOX-5, SOX-6, and SOX-9) to enhance the chondrogenesis of mesenchymal stem cells. Stem Cells Dev 2011;20:2103-14.
19. Lee JM, Im GI. SOX trio-co-transduced adipose stem cells in fibrin gel to enhance cartilage repair and delay the progression of osteoarthritis in the rat. Biomaterials 2012;33:2016-24.

20. Im GI, Kim HJ, Lee JH. Chondrogenesis of adipose stem cells in a porous PLGA scaffold impregnated with plasmid DNA containing SOX trio (SOX-5,-6 and -9) genes. Biomaterials 2011;32:4385-92.

21. Lee JS, Lee JM, Im GI. Electroporation-mediated transfer of Runx2 and Osterix genes to enhance osteogenesis of adipose stem cells. Biomaterials 2011;32:760-8

22. Kim KI, Park YS, Im GI. Changes in the epigenetic status of the SOX-9 promoter in human osteoarthritic cartilage. J Bone Miner Res 2013;28: 1050-60. 